\title{
El impacto de la historia de Jesús en la sistemática de Calcedonia
}

\author{
Samuel Fernández. \\ PONTIFICIA UNIVERSIDAD CATÓLICA DE CHILE \\ FACULTAD DE TEOLOGÍA \\ Non putemus non fuisse vera \\ quae Deo videntur indigna \\ (Leo Magnus, Sermo LII, 2).
}

\section{Introducción}

El presente artículo intenta hacer un recorrido por algunos puntos particulares del desarrollo de la cristología patrística hasta Calcedonia, seleccionados en función de su relevancia para mostrar cómo la revelación histórica de Dios en Jesús de Nazaret produjo un impacto que llevó a modificar el sistema de pensamiento. Si bien, la cristología se fue estableciendo gradualmente en el diálogo de ida y vuelta entre el acontecimiento histórico y las categorías de pensamiento, el propósito de este recorrido es mostrar sobre todo cómo la revelación histórica impactó de tal modo en la sistemática teológica que le exigió redefinir sus propias categorías de pensamiento.

En el presente artículo, el término bistoria se refiere al acontecimiento, es decir, a lo ocurrido (Geschichte), y no tanto a la narración de lo ocurrido que, científicamente o no, elabora el sujeto, es decir, el relato (Historie) ${ }^{1}$. Así también, el caracter histórico de la revelación se entiende como la convicción bíblica de que Dios se revela en la historia humana, es decir, en sus acontecimientos. El carácter histórico de la revelación, como conciencia histórica, es decir, la convicción de que la revelación está siempre situada culturalmente, no es enfrentado como tema, sino asumida en el método del presente trabajo.

1 Cf. voz Historia e historicidad en Sacramentum mundi, vol. III (Barcelona 1973), 429-443. 


\section{Jesús y las esperanzas de Israel:}

\section{Elpredicador de Galilea y Mesías esperado}

El primer capítulo de la relación entre historia y sistemática lo podemos ver en los mismos inicios de la cristología, aun en suelo judío, y se refiere a la afirmación básica del kerygma cristiano: Jesús es el Mesías.

La primera cristología -como toda cristología- se expresó por medio de las categorías culturales disponibles: en este caso, las del judaísmo del siglo I. Esta primera cristología se establece en el diálogo entre el acontecimiento de la revelación (bistoria) y las categoría culturales (sistemática).

Un modo radical de plantear la relación entre sistemática e historia es presentado por D. F. Strauss, que sospecha que las categorías precristianas influyeron a tal punto en la comprensión de Jesús que la cristología tiene más que ver con las esperanzas de Israel que con el hijo de María de Nazaret. La cristología, de este modo, se habría desarrollado guiada más por la esperanza mesiánica que por la historia de Jesús. Según Strauss, Israel aguardaba al Mesías con mucha esperanza, un grupo se convenció de que Jesús de Nazaret era el Mesías esperado y comenzó a aplicarle a Jesús lo que el Antiguo Testamento afirmaba acerca del Mesías. Así, la convicción de que Jesús era el Mesías llevó a los cristianos a crear una figura de Jesús por inducción dogmática. Y así, fueron compuestos los relatos evangélicos «de buena fe, pero sin un átomo de verdad histórica»². Según Strauss, el sistema (las expectativas mesiánicas) se habría impuesto por sobre la historia de Jesús de Nazaret (el acontecimiento).

Pero esta prioridad de las expectativas por sobre la historia es inadecuada por un motivo de fondo: un examen atento de las expectativas de Israel permite afirmar, en términos estrictos, que «Jesús no es el Mesías esperado por Israel», pues Jesús no coincide con las expectativas de Israel $^{3}$. La primera comunidad debió redefinir el concepto de Mesías para poder aplicárselo a Jesús. Baste recordar que el kerigma primitivo estaba centrado en la muerte y resurrección del Mesías Jesús, en circunstancias que ni la muerte ni la resurrección del Mesías formaban parte de las ex-

2 D. F. Strauss, Nueva vida de Jesús (Valencia 1905) 190.

3 Cf. S. SiLva, Jesús. ¿Por qué murió Jesús? Iniciación a los evangelios, vol. III (Santiago 2009), 553-581, especialmente, el apartado El escándalo mesiánico provocado por Jesús, 576-581; J.D.G. DunN, Jesús recordado (Navarra 2009) 445-560. 
pectativas mesiánicas dominantes ${ }^{4}$. Pablo, en su predicación en las sinagogas, tiene primero que probar que «el Mesías debía padecer y resucitan», es decir, redefinir el concepto de Mesías, y solo así puede afirmar que Jesús es el Mesías (cf. Hech 17, 2-3): «El hecho de la muerte y resurrección del Mesías Jesús requirió la reevaluación del mesianismo y una redefinición de cuál debía ser el rol de Jesús como Mesías» ${ }^{5}$. Algo semejante sucede con los demás títulos cristológicos.

Al terminar un documentado estudio, James Dunn afirma el carácter novedoso de la doctrina de la encarnación: «En síntesis, no hemos encontrado nada en el judaísmo precristiano o en el más amplio pensamiento religioso del mundo helenístico que ofrezca una explicación suficiente del origen de la doctrina de la encarnación ${ }^{6}$. Es necesario redefinir las expectativas precristianas para aplicárselas al Señor Jesús. Luego, en la primera cristología -aun en suelo palestino- el acontecimiento histórico de Jesús de Nazaret modificó el sistema de pensamiento?

\section{Jesús y nosotros:}

\section{Pensar el escándalo de la encarnación}

La novedad de la encarnación es un verdadero escándalo que, paradójicamente, tiene pretensión de universalidad ${ }^{8}$. Por ello, en el desafío de pensar el escándalo el cristianismo se juega la posibilidad de su pretensión universal. Una enseñanza irracional no puede tener pretensiones universales: se debe contentar con exigir un salto al vacío a sus propios adherentes.

En el ambiente patrístico, tanto desde dentro como desde fuera de la Iglesia, se percibe la resistencia a pensar la encarnación. Por una parte, desde dentro de la comunidad cristiana, se elaboran algunas soluciones extremas, y por ello paradigmáticas, que tienden a resolver el escándalo

4 Solo a partir de la muerte y la fe en la resurrección de Jesús, la primera comunidad busca textos en el Antiguo Testamento para mostrar que este Jesús es el Mesías.

5 J. D. G. Dunn, Beginning from Jerusalem (Michigan 2009), 216.

6 J. D. G. Dunn, Christology in the Making. A New Testament Inquiry into the Origins of the Doctrine of the Incarnation (Michigan 1989), 253.

7 Cf. G. Segalda, La cristologia del Nuovo Testamento (Brescia 1985), 65.

8 Los documentos disponibles no permiten reconstruir una cristología, por incipiente que sea, que no tenga pretensión de validez universal, y esta validez universal está vinculada a la existencia histórica de Jesús de Nazaret. Cf. R. MArTin, Carmen Christi. Pbilipians II. 5-11 in recent interpretation (Cambridge 1967) 253. 
suprimiéndolo; y, por otra, un par de filósofos, representantes del mundo helenístico rechazan la encarnación como indigna de Dios.

\section{Resistencia a la encarnación desde dentro}

La encarnación resulta escandalosa tanto para la mentalidad judía como para la mentalidad griega. Así, la primera Iglesia, constituida por judíos y griegos, encontró resistencia, también dentro de sí misma, para pensar la encarnación. De modo esquemático se presentan las diversas soluciones.

a. Solución de la cristología ebionita. Aquellos judíos que creyeron que Jesús era el Mesías, pero que comprendieron su mesianismo estrictamente dentro del horizonte del Antiguo Testamento, elaboraron una cristología muy baja. Proclamaban a Jesús como el Mesías que, por su fidelidad a la Ley, llegó a ser exaltado por sobre los demás?. El judeocristiano ebionita se mantiene fiel a su sistema de pensamiento, marcado por el monoteísmo y por la Ley de Moisés, como elementos innegociables, y no está dispuesto a aceptar nada que no quepa dentro de este horizonte: la identidad de Jesús es comprendida dentro de los límites del sistema de pensamiento religioso ya establecido ${ }^{10}$.

b. Solución de la cristología docetista. El cristianismo de base helenística rechaza la carne de Jesús. Las constantes referencias a las cartas de Juan (1Jn 4, 2-3; 2Jn 7) y, luego, de Ignacio a David, a María, a la comida y la bebida, a Pilatos y, sobre todo, a la pasión y la resurrección, destacan la realidad de la encarnación (Tral., IX, 1-2). El punto crucial del desacuerdo es la pasión: los docetas afirman que Jesucristo ha sufrido en apariencia (cf. Tral., X; Esm., II; V, 2). Y este desprecio por la carne se traduce en desinterés por los pobres (Esm., VI, 2). Lo que está en juego es la salvación: los que no confiesan que el Señor fue portador de carne serán portadores de muerte (cf. Esm., V, 2), porque la salvación requiere el contacto de Dios con lo histórico: la carne.

9 Cf. Ireneo, Adv. haer., I, 26, 2; Orígenes, C. Celso, V, 61, 65; Eusebio, HE, III, 27, 1-6.

10 Otro testimonio de la reacción judía ante la pretensión cristiana se encuentra el Diálogo con Trifón de Justino. Según este texto, el judío Trifón, habría afirmado: «Decir que ese vuestro Cristo preexiste como Dios antes de los siglos, y que luego se dignó nacer hecho hombre, y no es hombre que venga de hombres, no solo me parece absurdo, sino necio» (Dial., 48, 1). 
Según la gran noticia de Ireneo, los gnósticos afirman que el Salvador no tomó nada del hombre material ${ }^{11}$. De este modo, Cristo no puede padecer. Pues lo más chocante para la sensibilidad griega es la pasión. Esta tendencia a debilitar la humanidad de Jesús seguirá presente en el período postniceno, de un modo diverso, en Apolinar y los monofisitas.

c. Solución de la cristología divisiva. En ambiente gnóstico se propone otra solución, que parece contraria al docetismo pero, en realidad, es otra alternativa para rechazar la encarnación: la cristología que separa a Jesús hombre del Logos divino que habita en él ${ }^{12}$. Jesús, entonces, sería un hombre común, y dentro él habría descendido el Cristo superior en el bautismo, el cual se habría retirado antes de la pasión y, así, Jesús sufrió mientras el Cristo permanecía impasible. Esta mentalidad supone axiomáticamente que lo espiritual no puede padecer. En el Evangelio de Felipe, el grito de la cruz, «Dios mío, Dios mío, ¿por qué me has abandonado?» $\rangle^{13}$, es interpretado como el grito del Jesús hombre que se queja porque el Cristo divino lo abandona en la pasión. El modo de resolver el escándalo de la pasión es independizar lo espiritual de lo material en modo de liberar lo divino de los padecimientos, que son asumidos exclusivamente por el Jesús terreno ${ }^{14}$. De este modo, lo divino no entra en contacto con la historia.

Estas tres soluciones cristológicas tienen en común que resuelven el escándalo de la encarnación disolviéndolo: la primera suprime la divinidad y, luego, Jesús es un simple hombre; la segunda declara aparente la humanidad y, así, Jesús es Dios en apariencia de hombre; y la tercera resuelve el problema manteniendo la integridad de la humanidad y de la divinidad, pero independizando ambos elementos, dañando la unidad del sujeto. Es-

11 Cf. Ireneo, Adv. haer., I, 6, 1. Además: «Enseñó [Satornilo] que el Salvador no nació, es incorporal y sin figura, y que solo en apariencia se dejó ver de los seres humanos» (Adv. haer., I, 24, 2).

12 Cf. Ps.-Hipólito, Refut., VII, 33, 2; cf. Ireneo, Adv. haer., I, 25, 1; 26, 1.

13 EvF, 68. Asimismo, en el Evangelio de Judas, Jesús le dice a Judas: «Tú vas a superarlos a todos ellos, porque tú vas a sacrificar al hombre que me reviste» (p. 56). Así, Judas no traiciona al Cristo superior, sino solo al hombre Jesús, que es su «envoltorio».

14 Así también los ofitas: «Y cuando Jesús se encaminaba a la muerte, dicen ellos, el Cristo junto con la Sabiduría se apartaron de él y se volvieron a elevar al Eón incorruptible, y así solo Jesús fue crucificado» (Ireneo, Adv. haer., I, 30, 13, cf. I, 7, 2). 
tas soluciones, en que Dios no entra en la historia, fueron elaboradas sin modificar los respectivos sistemas de pensamiento.

\section{Resistencia a la encarnación desde fuera: Celso y Porfirio}

a. E1 Discurso verídico de Celso aporta elementos interesantes para el actual propósito ${ }^{15}$, pues muestra el choque entre la mentalidad helenística y las pretensiones del cristianismo. Ante la predicación cristiana, Celso dice que no hay que investigar cómo fueron las cosas, sino si acaso es una obra «digna de Dios» (cf. C. Celso II, 15-16). Así, según Celso, lo que determina los límites de la actividad divina es «lo que es digno de Dios y bueno» (C. Celso VII, 14) y no está dispuesto a que la realidad sea diferente. Da la prioridad a su sistema de pensamiento por sobre la historia. Por ello, considera absurdo que Dios tuviera que bajar a la tierra: le parece inaceptable la encarnación y la resurrección corporal ${ }^{16}$. De hecho, «el centro neurálgico en el debate entre Orígenes y Celso reside en la posibilidad de la revelación en la historia: ¿puede darse la gracia? Para Celso, la doctrina cristiana significa que la libertad de Dios es arbitraria y caprichosa» ${ }^{17}$.

b. El Contra los cristianos de Porfirio refleja opiniones semejantes a las de Celso acerca de la encarnación. Hay que recordar que Porfirio inicia la vida de su maestro diciendo que Plotino «se avergonzaba de estar en un cuerpo» (Vida I, 1). Esta aversión al cuerpo, típica del ambiente platónico, no podía sino incidir en el juicio de este filósofo acerca de la encarnación. Tanto la encarnación como la localización concreta de Dios en la tierra le parecen a Porfirio una cosa absurda, inferior a las creencias más despreciables de los griegos más incultos. Además, rechaza la pretensión de universalidad de Cristo, que vino en un tiempo determinado (cf. fr. 81; 84; 77; 82).

15 Cf. S. Benko, «Pagan Criticism of Christianity During the First Two Centuries A.D.», en H. Temporini-W. HaAse (ANRW, II 23/2, Berlin-New York 1980), 1055-1118; S. FernándeZ, «El Discurso verídico de Celso contra los cristianos. Críticas de un pagano del siglo II a la credibilidad del cristianismo», Teología y Vida, XLV (2004) 238-257.

16 Cf. Orígenes, Contra Celso IV, 3; IV, 5-6; IV, 14; IV, 18; V, 2; I, 69-70; III, 41; II, 55 (contra la bajada de Dios y la encarnación). La resurrección de la carne le parece una esperanza digna de gusanos, apegados al cuerpo, cf. Contra Celso V, 14; VII, 33-34; VI, 36.

17 H. CHADwick, Early Christian Thought and the Classical Tradition (Oxford 1966), 120. Cf. M. FÉdou, Christianisme et religions païennes dans le Contre Celse d'Origène, 536-537. 
Este choque entre el cristianismo y los intelectuales griegos remite a la vexata quaestio de la tesis de Adolf von Harnack sobre la belenización del cristianismo comprendida como corrupción ${ }^{18}$. Según esta tesis, la teología cristiana sacrificó lo propio en función de una adaptación indiscriminada al espíritu helenístico. Pero si la teología cristiana patrística hubiese renunciado a su novedad y se hubiese adaptado sin más al helenismo, no habría encontrado una oposición intelectual tan fuerte como la de Celso o Porfirio. Por otra parte, la tesis de la helenización del cristianismo supone un helenismo compacto y unitario, ante el cual el cristianismo se habría rendido, en circunstancias que la investigación histórica reciente nos ofrece un cuadro bien diferente: el período helenístico es una época marcada por el pluralismo ideológico ${ }^{19}$. Ante la constatación del pluralismo del pensamiento helenístico, es posible preguntar: ¿Por qué el cristianismo optó, en cada aspecto, por una visión filosófica frente a varias?, ¿por qué a veces optó por el platonismo, otras por el estoicismo y otras por el aristotelismo? Cuando se observan de cerca las opciones filosóficas de la teología cristiana se tiene la impresión de que en cada punto se realizó un discernimiento entre las diversas posturas, a veces irreconciliables, presentes en el helenismo. Finalmente, una tercera observación a la tesis de Von Harnack nace de la constatación histórica de que, para pensar y transmitir los elementos más característicos del evangelio, la teología cristiana no encontró conceptos ya establecidos, sino que debió acuñar un lenguaje nuevo, otorgando un contenido nuevo a palabras que, en su uso corriente, tenían otro significado, como sucedió en las polémicas trinitarias del siglo IV.

18 Cf. W. Pannenberg, «La asimilación del concepto filosófico de Dios como problema dogmático de la antigua teología cristiana» en Cuestiones fundamentales de teología sistemática (Salamanca 1976), 93-149; L. SCHEFFCZYK, «La helenización del cristianismo: Reflexiones de actualidad», RET 41 (1981), 469-481; J. RATZInger, El Dios de la fe y el Dios de los filósofos (Madrid 2007).

19 Si bien se había producido cierta fusión entre las diversas escuelas filosóficas clásicas, persistían diferencias radicales entre las corrientes de pensamiento que constituyen lo que hoy llamamos indiferenciadamente el helenismo. 


\section{Jesús y Dios:}

Pensar la novedad de la revelación trinitaria ${ }^{20}$

De la preocupación cristológica, pasamos a la trinitaria, es decir, la relación entre Jesús y Dios. La alteridad entre el Padre, el Hijo y el Espíritu Santo es un dato evidente aportado por la historia de Jesús y por la vida de la Iglesia, en especial, por la oración y la liturgia: la comunidad reza y bautiza en el nombre del Padre, del Hijo y del Espíritu Santo. Esta alteridad, al ser evidente, no es reflexionada, sino pacíficamente asumida. Pero, entre los que, en el siglo II, intentan armonizar la alteridad y la fe monoteísta, algunos optarán por identificar personalmente al Hijo con el Padre (monarquianos), mientras otros preferirán rechazar la divinidad de Cristo (ebionitas y adopcionistas). Novaciano transmite la lógica de estas propuestas:

«Si hay un solo Dios, y Cristo es Dios, Cristo es el Padre, porque Dios es uno solo. Si Cristo no fuera el Padre, dado que Cristo, en cuanto Hijo, es también Dios, parece que se han introducido dos dioses contra las Escrituras».

«Si el Padre es uno y el Hijo es otro distinto, y el Padre es Dios y Cristo es Dios, no hay por tanto un único Dios, sino que se introducen a la vez dos dioses, el Padre y el Hijo. Pero si hay un único Dios, consiguientemente Cristo es un hombre, de modo que con razón el Padre es el único Dios» (Trin., xxx, 175).

La lógica de los textos es impecable e implacable. El carácter silogístico del razonamiento acusa la matriz griega de estos monarquianos. Ambos grupos buscan mantener la unidad de Dios, y ambas soluciones sostienen algo y sacrifican algo para mantener el monoteísmo:

a. Un grupo profesa la divinidad del Hijo, pero sacrifica su alteridad respecto del Padre: se trata de los monarquianos que identifican el Hijo con el Padre. Entre ellos se cuentan Noeto, Praxeas y Sabelio. Esta doctrina, a primera vista, declara que Dios mismo entra en la historia,

20 Cf. A. Milano, Persona in teologia. Alle origini del significato di persona nel cristianesimo antico (Napoli 1984) 98-153; R. CANTALAmessa, «L'evoluzione del concetto di persona nell'uso trinitario e cristologico antico» en R. CANTAlamessa, Dal kerygma al dogma. Studi sulla cristoligia dei Padri (Milano 2006) 141-150; M. SimonetTI, "Persona” nel dibattito cristologico dal III al VI secolo» 91 (Roma 1995) 529-548. B. SEsBoüÉ, Historia de los dogmas, vol. I. El Dios de la Salvación (Salamanca 1995) 224-240; C. Andressen, «Zur Entstehung und Geschichte des trinitarischen Personbegriffes» en Zeitschrift für die Neutestamentliche Wissenschaft und die Kunde der älteren Kirche, 52 (1961) 1-39. 
pero, en realidad, la teología monarquiana exige una cristología divisiva. Así, en esta doctrina, Dios no toca la historia.

b. Otros grupos, para mantener la alteridad del Hijo respecto del Padre, sacrifican la divinidad de Cristo: los adopcionistas y ebionitas, dentro del horizonte cultural judío, reconocen en Jesús al Profeta y al Mesías, que es un simple hombre, pero que, por su vida excepcional, fue elevado y adoptado por Dios hasta una categoría superior. En esta solución Dios no entra en la historia: Jesús es plenamente histórico, pero no es divino.

Es interesante notar que, aun en el tema trinitario, tan intrateológico, un filósofo pagano tiene también una palabra que decir. Según Celso, el «culto excesivo» que la Iglesia otorga a Jesús contradice el monoteísmo que ellos mismos dicen profesar ${ }^{21}$. De este modo, según él, la divinidad de Cristo daña el monoteísmo. También Porfirio critica la teología de la generación y la filiación del Logos (cf. fr. 85; 86).

Todos estos grupos intentan comprender la novedad de la revelación histórica sin romper los marcos de sus propias categorías culturales: no están dispuestos a modificar su modo de comprender el monoteísmo y, por lo tanto, dejan fuera la estricta novedad de la revelación histórica. Por el contrario, la línea teológica que se impondrá, para mantener su fidelidad a la regla de fe, ensaya una ampliación de las categorías intelectuales para hacerlas capaces de acoger la novedad revelada en la historia de Jesús. Esta ampliación de la razón, para pensar adecuadamente la novedad de la revelación, por naturaleza, es una tarea siempre inacabada ${ }^{22}$.

De este modo, «el concepto "persona" surgió en relación con la Escritura, como exigencia para su interpretación. Es un producto de la relación

${ }^{21}$ Cf. Contra Celso VIII, 12. Frente a esta objeción de Celso, Orígenes explica de acuerdo a que el Padre y el Hijo son dos y de acuerdo a que ambos son un solo Dios.

22 Cf. Benedicto XVI, Discurso a la IV Asamblea nacional eclesial en Italia (19 octubre 2006): «Sobre estas bases resulta de nuevo posible ensanchar los espacios de nuestra racionalidad, volver a abrirla a las grandes cuestiones de la verdad y del bien, conjugar entre sí la teología, la filosofía y las ciencias, respetando plenamente sus métodos propios y su recíproca autonomía, pero siendo también conscientes de su unidad intrínseca. Se trata de una tarea que tenemos por delante, una aventura fascinante en la que vale la pena embarcarse, para dar nuevo impulso a la cultura de nuestro tiempo y para hacer que en ella la fe cristiana tenga de nuevo plena ciudadanía». 
del hombre con la Biblia» ${ }^{23}$, es decir, un concepto tan central para el pensamiento occidental como el de persona surge de la historia bíblica. Jesús, en los evangelios, se autodefine por su relación con el Padre, y por ello la relación entre el Padre y el Hijo ya no podía ser vista como accidental. Era necesario otorgar a la categoría de relación una densidad mayor que la que le concedía Aristóteles (como accidente de la sustancia). El carácter correlativo del Padre y el Hijo, destacado por los alejandrinos ${ }^{24}$, tendrá su cumbre con Agustín: la historia de Jesús exige repensar la conexión entre conceptos tan fundamentales como ser y relación ${ }^{25}$.

Se trata de un problema central, que ya se ha visto a propósito de la encarnación: la teología cristiana no encontró conceptos adecuados para pensar y transmitir la revelación trinitaria, sino que debió crear un lenguaje nuevo que le permita acceder a nuevos ámbitos de la realidad. A pesar de la enorme riqueza de la lengua filosófica griega, los cristianos, algunos de ellos expertos conocedores de la filosofía helenística, no encontraron los moldes adecuados para comprender la realidad que hallaban revelada históricamente en Jesús. Por ello, en cierto sentido, fue necesario inventar un lenguaje nuevo, fijando con precisión técnica el contenido de ciertos términos. Son muy elocuentes las palabras de san Jerónimo, escritas el 376, es decir, solo cinco años antes que el concilio de Constantinopla I,

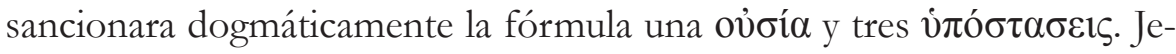
rónimo, en una carta al papa Dámaso, afirma que la lengua clásica considera hypóstasis y ousía como sinónimos: «Toda la tradición de las letras profanas no entiende por hypóstasis otra cosa que ousía» y dice que prefiere hablar de una sola hypóstasis en Dios (Ep., xv, 4). Algo semejante se puede apreciar en el Tomo a los antioquenos de san Atanasio.

23 J. Ratzinger, «Sobre el concepto de persona en la Teología» en J. Ratzinger, Palabra en la Iglesia (Salamanca 1975), 169. Cf. Tertuliano, Adv. Praxean, XI, 7-10.

24 Orígenes: «Necesariamente el Hijo es Hijo de un Padre, y que el Padre es Padre de un Hijo», In Ioh. Com., X, 246; Dionisio de Alejandría: «Digo "Padre" y, antes que introduzca al Hijo, lo implico, también a él, en el Padre. Introduzco al Hijo y, aun si no mencionara al Padre, de todos modos lo presupondría en el Hijo. Propongo al Espíritu Santo y, al mismo tiempo, incluyo a Aquel de quien y a Aquel por medio del cual proviene», De sententia Dionysii, 17. Cf. X. Morales, La Théologie trinitaire d'Athanase d'Alexandrie (Paris 2006) 203-204.

25 De Trin., V, V, 6: «En Dios, nada se afirma según el accidente, porque nada mudable hay en Él; pero no todo cuanto de Él se enuncia se dice según la sustancia. Se habla a veces de Dios según la relación (ad aliquid). El Padre dice relación al Hijo, y el Hijo dice relación al Padre, y esta relación no es accidente». 


\section{Jesús y la sistemática: \\ La historia de Jesús en la cristología de Calcedonia}

La cristología de Calcedonia ha sido severamente criticada en las décadas pasadas $^{26}$. Una de estas críticas sería que «Calcedonia prescinde absolutamente de la historia personal de Jesús ${ }^{27}$. La crítica es justificada si se identifica la cristología de Calcedonia con la definición de Calcedonia. Pero no corresponde exigir a una definición de fe que contenga toda la riqueza de la cristología. De hecho, un autor poco anterior a Calcedonia, tan sensible a la humanidad de Jesús, comprende las condiciones propias de una profesión de fe y reconoce que toda la historia de Jesús se debe ver implícita en las palabras del Credo de Nicea: «nació de la Virgen María y fue crucificado en tiempo de Poncio Pilatos $\rangle^{28}$.

Se trata, entonces, de estudiar la riqueza que subyace a Calcedonia, y no solo el texto de la definición. Por ello, en primer lugar, no se abordará la definición dogmática, sino la cristología de León Magno, un autor cuya contribución «fue decisiva para la elaboración de la fe de Calcedonia» ${ }^{29}$.

\section{Cristología pastoral de san León Magno}

Por los motivos señalados, la cristología del papa León no será reconstruida a partir del Tomo a Flaviano -como suele hacerse-, sino a partir de sus homilías litúrgicas dirigidas al pueblo. El interés de las cartas doctrinales de León es dogmático y conceptual y, por ello, su cristología dominante es descendente y toma poco en consideración la historia de Jesús; por el contrario, en sus sermones al pueblo, donde la preocupación soteriológica está al centro, junto a la cristología descendente, se encuentran significati-

26 A este propósito, se puede consultar el excelente estudio de B. SESBOÜÉ, «Le procès contemporain de Chalcédonie. Bilan et perspectives», RSR 65 (1977) 45-80.

27 B. SESBOÜE, «Le procès contemporain de Chalcédonie», 52.

28 Teodoro de Mopsuestia afirma que los padres de Nicea, al indicar el inicio y el fin de la economía, es decir, la encarnación y la pascua, «comprenden entre esos dos extremos todas las cosas que una tras otra nos enseña el libro del Evangelio», Homilías catequéticas, VI, 9, en R. Tonneau - R. Devreesse, Les homélies catéchtiques de Théodore de Mopsueste (Città del Vaticano 1949) 145-147.

29 B. Studer, en A. Di Berardino, Patrología III. La edad de oro de la literatura patrística latina BAC 422, (Madrid 1986) 735. En la Actio III, es decir, la sesión del 10 de octubre del 451, se leen y se pide la aprobación de los siguientes documentos: el símbolo de Nicea, el símbolo de Constantinopla, la II carta de Cirilo a Nestorio, la carta de Cirilo a Juan de Antioquía (La fórmula de unión del 433) y el Tomo de León a Flaviano. 
vos elementos de cristología ascendente que parten de la historia de Jesús: no solo se afirma que el Hijo de Dios se hizo hombre, sino que «el Hijo del hombre se mostró Hijo de Dios» (Sermo 74, 4) ${ }^{30}$. Esta presentación, desde abajo, otorga valor salvífico a toda la historia de Jesús ${ }^{31}$. Historia que es accesible por medio de los evangelios, la liturgia y la tradición (cf. Sermo 56, 1), en modo que todo cristiano puede participar de la experiencia de los primeros seguidores de Jesús:

«Nosotros, sin alejarnos en nada de los testimonios evangélicos y apostólicos, seamos fortalecidos con la comprensión de aquellos que nos instruyeron con su ciertísima experiencia (experimenta), para que piadosa y firmemente podamos decir que, en ellos, también nosotros hemos sido instruidos, que hemos visto lo que ellos vieron (quod viderunt uidimus), que hemos aprendido lo que ellos aprendieron y hemos palpado lo que ellos tocaron» (Sermo 64, 1).

Con esta convicción, llama al pueblo a aceptar «sin ninguna duda lo que los santos evangelios, escritos por el dedo de Dios, testifican acerca de la pasión» (Sermo 69, 3). León no busca un Jesús detrás del texto, sino que ve en los escritos evangélicos el acceso a la historia de Jesús de Nazaret ${ }^{32}$. El papa León, entonces, si bien es heredero de una tradición cristológica descendente, reconoce que el punto de arranque de la elaboración de la cristología no es una deducción dogmática (como debería ser un Dios encarnado), sino la concreta historia del Jesús de los evangelios:

«Queridos hermanos, leyendo o escuchando el evangelio, reconocéis algo en el Señor Jesucristo sujeto a injurias y algo iluminado por los milagros, en modo que en el mismo se manifiesta lo humano y resplandece lo divino» (Sermo 46, 2).

Así, a partir del evangelio, es decir, al recorrer las acciones de la historia de Jesús, se reconoce la duplicidad de naturalezas y la unidad del sujeto:

30 Se usa el texto: Sancti Leonis Magni, Tractatus septem et nonaginta, rec. A. Chavasse (Corpus christianorum, Series Latina 138 y 138a; (Turnhout 1973). Las traducciones son propias.

31 León Magno, Sermo 74, 1: «El misterio de nuestra salvación [...] se cumplió, por medio de la humildad, desde el día del nacimiento corporal hasta el fin de la pasión».

32 Otros autores, con mayor conciencia histórica, establecen una cierta distinción entre los relatos evangélicos y el histórico Jesús de Nazaret. Así, Orígenes, cf. In Ioh. Com., II. 
«Simultáneamente aparece a los corazones rectos, en la única y misma persona, tanto la humildad humana como la majestad divina» (Sermo $37,1)$.

El obispo de Roma exhorta a su auditorio, en un magnífico texto, a valerse de la historia evangélica para penetrar en la comprensión del Salvador:

«Mente cristiana, huyendo de la mentira y siguiendo a la verdad, utiliza con confianza de la historia evangélica (utere euangelica fidenter historia) y, como si tú misma estuvieses junto a los apóstoles, discierne tanto con la inteligencia espiritual como con la mirada corpórea lo que visiblemente ha sido hecho por el Señor» (Sermo 46, 2).

El punto de partida de la comprensión de Cristo es la historia de Jesús. Por ello es necesario utilizar, es decir, valerse de la historia evangélica (utere). El mismo texto supone un método teológico que parte de la historia de Jesús, presentada por los evangelios, que permite al cristiano ser contemporáneo de los apóstoles, y que requiere, para comprender a Cristo, tanto la mirada espiritual como la visión corporal porque, para la salvación, interesa tanto lo divino como lo humano. San León toma muchos ejemplos evangélicos que muestran que el único y el mismo es el que realiza acciones plenamente divinas y plenamente humanas: el mismo que es envuelto en pañales es adorado por los magos; el mismo que participa del banquete convierte el agua en vino; el mismo que lloró a Lázaro, resucitó a Lázaro; el mismo que trabaja con barro y saliva cura al ciego de nacimiento; el mismo que duerme por el cansancio calma la tempestad (cf. Sermo 46, 2). Asimismo, después de la resurrección, el Salvador se manifestó a los discípulos y a las mujeres: entró, estando las puertas cerradas (divinidad), y les mostró sus llagas (humanidad):

«Para que fuera reconocido (ut agnosceretur), en él, que permanecían distintas las propiedades de las naturalezas divina y humana» (Sermo 71, 3).

León Magno busca defender la integridad de la humanidad de Cristo aun después de su resurrección: es necesario que reconozcamos (agnoscamus) en él nuestras propiedades (cf. Sermo 72, 5), pues la humanidad no queda absorbida y sus características pueden ser reconocidas en el Resucitado. De este modo, la fórmula de cristológica «una persona en dos naturalezas» no es una simple deducción dogmática, sino un intento de expresión conceptual, a partir de los términos griegos, de la historia de Jesús transmitida por los evangelios: nuevamente, esta fórmula no existía 
en la antropología anterior al cristianismo y debió ser inventada en función de la cristología $a^{33}$. Esta fórmula cristológica busca, entonces, expresar conceptualmente la unidad del sujeto y la verdad de las acciones de Jesús narradas por los evangelios:

«Cada una de las naturalezas, por medio de diferentes acciones, expresan su verdad, pero ninguna de las dos disuelve la unión con la otra» (Sermo 54, 1).

A partir de las acciones se llega a la duplicidad de naturalezas en la unidad del sujeto. Y continúa: «Allí nada falta de ambas: toda la humildad está en la majestad, y toda la majestad está en la humildad» (Sermo 54,1) No hay competencia entre lo divino y lo humano. En esta unidad, no es necesario sacrificar la divinidad por la humanidad, o la humanidad por la divinidad: ni la divinidad absorbe a la humanidad, ni la humanidad vulnera a la divinidad ${ }^{34}$. Más aún, ambas son necesarias por motivos soteriológicos. La verdad de la condición divina y de la condición humana en la unidad de la persona, según León, es la condición necesaria para la salvación:

«Si tanta diversidad no hubiera concurrido en uno solo, la naturaleza humana no habría podido ser reconciliada con Dios» (Sermo 37, 1).

Para la reconciliación no solo es necesaria la integridad de humanidad y divinidad, sino también su unidad personal, es decir, que el hombre y Dios se unan verdaderamente en Cristo:

«Por este nacimiento admirable, la Virgen santa ha dado al mundo una persona única, verdaderamente humana y verdaderamente divina [...] pues tal es la unidad de esta diversidad respectiva (in tantam tamen unitatem convenit utriusque diversitas) que el Hijo es uno y el mismo» (Sermo $23,1)$.

Esta convicción soteriológica requiere la verdad de ambas naturalezas y la unidad del sujeto, solo así la obra histórica de Jesús es salvífica para la humanidad, tal como lo afirma comentando la oración del huerto:

«Por estas palabras [Padre, si es posible, pase de mí este cáliz], reveladoras de cierto temor, curaba las emociones de nuestra de-

33 Hay que recordar que $\varphi v ́ \sigma ı \varsigma$ e vं sinónimos. Cf. S. Zañartu, Historia del dogma de la encarnación desde el s. V al VII (Santiago 1994) 49-58; M. RichARD, «L'introduction du mot «hypostase» dans la théologie de l'incarnation», Mélanges de Science Religieuse, 2 (1945), 5-32. 243-270.

34 Cf. Sermo 27, 1: «Deitas enim, quae illi cum Patre communis est, nullum detrimentum omnipotentiae subiit, nec Dei formam serui forma uiolauit». 
bilidad tomando parte en ellas y, sometiéndose, destruía el miedo a la pena que había de sufrir. El Señor temblaba en nosotros con nuestro temon» (Sermo 54, 4).

Con esta programática preocupación soteriológica, León insiste en que Dios y el hombre realmente se han unido en Cristo: el Señor tiembla con nuestro temor. Ahora bien, estas paradójicas afirmaciones chocan tanto con «la doctrina judía» como con «la sabiduría pagana». Por medio de estas expresiones, san León Magno presenta retóricamente las dificultades racionales para aceptar la cristología: la doctrina judía (ebionita) no acepta la divinidad de Jesús, mientras la sabiduría pagana (docetista) no acepta la humanidad del Hijo de Dios:

«Que ni la ofensa judía ni la burla pagana corrompa la integridad de la sana inteligencia, para que lo que ha sido hecho (quod gestum est) en favor nuestro, no solo de modo humilde sino también sublime, ni parezca imposible de acuerdo al hombre ni parezca indigno de acuerdo a Dios» (Sermo 56, 1).

Para unos, es imposible que un hombre sea Dios (solución ebionita) y para otros es indigno que Dios sea hombre (solución docetista). Pero la sana inteligencia acepta lo que encuentra revelado en la historia evangélica: «quod gestum est» (resuena el adagio: contra factum non est argumentum). De hecho, «la ceguera de los judíos no ve lo que es divino en Cristo Jesús, mientras la sabiduría de los paganos desprecia lo humano» (Sermo 56, 2). La cumbre de la paradoja de la historia de Jesús se encuentra, naturalmente, en la cruz:

«Pues, ¿qué fue aquello que quitó la inteligencia a los judíos y confundió la el corazón de los sabios del mundo; que anuló la prudencia filosófica y ofuscó la doctrina israelita, si no la cruz del Hijo de Dios?» (Sermo 70, 3).

Que el Hijo de Dios naciese de una Virgen y fuera clavado en la cruz «parecía ilógico e irracional». Ahora bien, lo que parecía (videbatur) irracional (inrationalis) goza de la razón de la misericordia (misericordiae ratio) que no anula «la majestad del que se compadece»35. De este modo, León Magno propone un interesante principio: «no pensemos que no fue ver-

35 Cf. León Magno, Sermo 70, 3: «Parecía inconsecuente e irracional aceptar en el alma que el Creador de toda naturaleza, en la sustancia de hombre verdadero, naciese de una Virgen intacta, que el Hijo de Dios igual al Padre, el que llena todo y contiene todo, fuera aferrado por la manos de los inicuos y condenado por el juicio de los injustos y después de las burlas humillantes se dejara clavar en la cruz. Pero en todo 
dadero lo que parece indigno de Dios (quae Deo videntur indigna)» (Sermo 52, 2). La frase es muy significativa: lo que parece indigno de Dios no puede ser criterio de verdad, porque lo que parecía indigno de Dios e imposible para el hombre, de hecho, se ha realizado en la historia:

«Hemos reconocido que en nuestro Redentor concurren dos naturalezas, y, conservando sus propiedades, se ha realizado una tal unidad de ambas sustancias que, desde aquel tiempo (ab illo tempore), en que el Verbo se hizo carne en el vientre de la Santa Virgen -tal como lo requería el género humano-, no es lícito pensar que él es Dios sin aquello por lo que es hombre, ni pensar que es hombre sin aquello por lo cual es Dios» (Sermo 54, 1).

Tal como aparece en otros textos, en la historia de Jesús se reconocen las dos naturalezas y la unidad de la persona, es decir, «lo requería el género humano» (preocupación soteriológica). Pero la particularidad de este texto radica en que afirma que desde un momento histórico (ab illo tempore), es decir, el momento de la encarnación, se introduce un nuevo modo de pensar a Dios y al hombre. Si bien, en los sermones al pueblo, se encuentra más profesión de fe que teología, de todos modos, el papa León no proclama solo fórmulas antitéticas, más retóricas que teológicas, sino que invita a pensar al hombre y a Dios a partir de la realidad histórica de la encarnación. No hay un rechazo de la razón, sino una invitación a ampliar la razón a partir de la historia de Jesús de Nazaret comprendida como revelación de Dios.

\section{Presencia de la historia en la definición de Calcedonia}

Este recorrido por algunos puntos de la cristología de León Magno permite decir una palabra acerca de la definición de Calcedonia. Tal como se ha visto, san León afirma en sus sermones al pueblo, que en las acciones de Jesús narradas por los evangelios se expresan, se muestran, aparecen, se manifiestan, se reconocen (agnoscetur), las dos naturalezas de Cristo y la unicidad de su persona. A la luz de esta constatación, se puede reconocer en la definición de Calcedonia algo de la historia de Jesús, contenida en

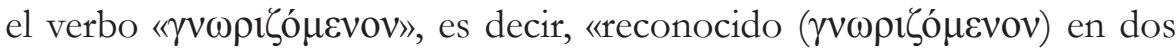
naturalezas sin confusión, sin cambio, sin división, sin separación» ${ }^{36}$. Este

esto se encuentra a la vez la humildad del hombre y la altura de la divinidad, y la razón de la misericordia no oscurece la majestad del que se compadece».

36 Actio V, 34, en E. SchWArT, Acta Conciliorum Oecumenicorum, II, 1, 325-326 (= ACOe). Traducción inglesa en R. Price - M. GadDis, The Acts of the Council of Chalcedon, vol. 
texto capital de la definición, según las Actas de Calcedonia, recibió el influjo de la cristología de León Magno ${ }^{37}$. La primera redacción de la definición era más estática y decía «confesamos que Cristo es a partir de dos naturalezas», según la profesión de Flaviano ${ }^{38}$, fórmula que ni los antioquenos, ni los romanos aceptaron.

El verbo $\gamma v \omega \rho i ́ \zeta \omega$ significa conocer, reconocer, certificar la identidad de una persona, y equivale a agnosco en latín, que es utilizado por León en referencia a las naturalezas. En las Actas de Calcedonia, este verbo, referido a las naturalezas de Cristo, es usado varias veces por Basilio de Seleucia, en especial en su profesión de fe del sínodo del 448, en que afirma «Un solo Señor nuestro Jesucristo reconocido en dos naturalezas $»^{39}$. Un interesante pasaje muestra el sentido de verbo:

«Aecio dijo: "Pedimos leer el texto de las actas que han traído, para reconocer $\left(\gamma \nu \omega \rho i ́(\omega \mu \varepsilon v)\right.$ de quién es la mano [del escrito]"»" ${ }^{40}$.

Asimismo, según las Actas de Calcedonia, después de observar un do-

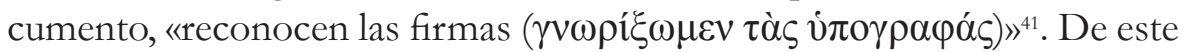
modo, al ver la presentación exterior y física del manuscrito, se reconoce de

II (Liverpool 2007) 194-205, y francesa en A.-J. Festugière, Actes du Concile de Chalcédoine (Genève, 1983) 57-65.

37 Así aparece explícitamente en las Actas: «Los reverendísimos obispos del Ilírico dijeron: "Que los que se opongan, se identifiquen. Los disidentes son nestorianos. Que los disidentes se vayan a Roma". 26. Los grandes y gloriosos oficiales dijeron: "Dióscoro dijo: 'Lo de a partir de dos naturalezas, lo acepto; pero lo de dos, no lo acepto'. Pero el más santo Arzobispo León dice que hay dos naturalezas en Cristo, unidas sin confusión, cambio o separación en el único Hijo Unigénito, Nuestro Salvador. Así pues, ¿̇a quién van a seguir, al más santo León, o a Dióscoro?”. 27. Los obispos reverendísimos exclamaron: "Nosotros creemos como León. Los que se oponen son eutiquianos. La enseñanza de León es ortodoxa". 28. Los grandes y gloriosos oficiales dijeron: "Entonces agreguen a la definición, de acuerdo con el decreto de nuestro santo Padre León, que, en Cristo, hay dos naturalezas unidas sin cambio, sin división y sin confusión"», Actio V, 25-28 (ACOe, II, 1, 321).

38 Texto original en $A C O e$, II, 1, 1, 114.

39 Actio I, 301, cf. Actio I, 169; I, 172; I, 176; I, 532. Sin negar el influjo de León en la definición de Calcedonia, De Halleux, insiste en la influencia de Basilio de Seleucia en este texto, cf. A. DE HALLEux, «La définition christologique à Chalcedoine», RTL 7 (1976), 3-23. 155-170.

40 Actio I, 610.

41 Actio IV, 23. 
quién es la letra o las firmas, y, análogamente, al ver las acciones históricas de Jesús, se reconocen presentes las dos naturalezas y el único sujeto.

Por eso, el texto de Calcedonia no dice «constituido» por dos naturalezas, sino «reconocido» en dos naturalezas, porque ellas no solo son, sino que se manifiestan en la historia de Jesús; o mejor: dado que se manifiestan sabemos que son. Las acciones históricas de Jesús de Nazaret revelan su ser: ellas son el punto de arranque desde el que se reconoce su identidad. La definición de Calcedonia, que expresa en términos ontológicos la identidad del Hijo de Dios hecho hombre, es un intento de expresar, en las categorías disponibles a los padres de Calcedonia, aquello se mostró en la historia de Jesús de Nazaret: en su vida terrena pueden ser reconocidas ambas naturalezas y el modo en que ellas están unidas, es decir, «sin confusión, sin cambio, sin división, sin separación». Esta constatación permite ensayar una interpretación de orientación más fenomenológica y dinámica de la definición de Calcedonia.

\section{Conclusión}

Una de las constantes seguidas en este recorrido del desarrollo del dogma es necesidad de redefinir las categorías de pensamiento para adentrarse en la comprensión de la revelación histórica de Dios en Jesús. Esta necesidad no se verifica solo en el paso del cristianismo desde la cultura judía al ambiente helenístico, sino también en suelo palestino: ya los primeros discípulos debieron redefinir el concepto de mesías para poder aplicárselo a Jesús de Nazaret.

Esto nos muestra que la dificultad de pensar a Jesús de Nazaret en categorías griegas no es solo un problema de la cultura griega, sino un caso particular de la dificultad general del ser humano para pensar la novedad de la revelación histórica. En ambiente palestino no encontramos una cristología neutra, en estado puro, sino una cristología ya comprendida en categorías culturales determinadas: también la cristología del NT es una cristología situada. De este modo, el cristianismo patrístico no es la corrupción helenística del cristianismo palestino, sino la parcial e imperfecta versión helenística del cristianismo, así como el NT nos ofrece la versión palestina. No debemos reprochar, sino alabar a los griegos que pensaron la fe en sus propias categorías.

El carácter escandaloso de la encarnación y novedoso de la revelación trinitaria deja en evidencia la insuficiencia de las categorías humanas 
(tanto judías como griegas) para pensar la revelación histórica de Dios en Jesús. Las herejías aludidas muestran que, para pensar el escándalo de la encarnación y la novedad trinitaria, era necesaria una reforma de las mismas categorías de pensamiento.

Los ebionitas rechazan la divinidad de Jesús, porque no entra en su modo de comprender el monoteísmo. Ellos piensan dentro de los límites que les permite Moisés. De este modo, lo realmente novedoso de la revelación histórica, por definición, no puede ser acogido. Los docetistas, por su parte, rechazan la carne de Jesús, porque la consideran indigna de Dios: su valoración negativa de la materia y su aversión al cuerpo, propias del ambiente griego, prevalecen por sobre la revelación histórica del Logos hecho carne (Jn 1, 14). Algo semejante ocurre con los que sostienen la cristología divisiva: para ellos, el Dios verdadero no puede entrar en la historia y, por eso, elaboran una cristología que independiza el elemento humano del divino en Jesucristo. El monarquianismo, a su vez, por medio de una deducción silogística, identifica a Jesús con el Padre para mantener incólume su modo de entender el monoteísmo, desconociendo la alteridad entre el Hijo y el Padre tan claramente manifestada en la historia de Jesús. En todos estos casos el sistema de pensamiento obliga a rechazar elementos del Dios revelado en la historia de Jesús. Lo mismo se aprecia entre los intelectuales paganos: a partir de su idea de Dios y de mundo rechazan axiomáticamente la encarnación, porque es indigno de Dios entrar en contacto real con el mundo.

Ahora bien, ¿cuál fue el camino que recorrió la teología cristiana? Para responder esta pregunta, hay que diferenciar «la profesión de fe» de «la teología». Desde el inicio la fe cristiana es profesada correctamente, pero sin que sea capaz de elaborar un discurso que se haga cargo de las dificultades intelectuales de las afirmaciones que se profesan en la regla de fe: se confiesa la humanidad, la divinidad y la unidad de Cristo; se profesa el monoteísmo, la divinidad de Jesús y la alteridad entre el Hijo y el Padre; pero no da una explicación racional de cómo se armonizan esas afirmaciones. Sin embargo, junto a esta profesión de fe, también desde el inicio, los doctores cristianos intentaron articular un discurso intelectual capaz de dar razón de la fe que se profesa. En este desarrollo se suceden soluciones insuficientes (las herejías) que van siendo criticadas y completadas por otras.

Pero dadas las exigencias de la revelación histórica, profesada por la fe de la Iglesia, la teología cristiana no logra elaborar un sistema armónico 
sin modificar el propio sistema de pensamiento: las categorías, tanto del judaísmo como del helenismo, son incapaces de acoger el contenida de la revelación histórica y, por ello, la teología cristiana debió emprender la impresionante tarea de modificar las categorías racionales para pensar la fe.

Pero, ¿se puede pensar el escándalo de la encarnación?, ¿se puede pensar la novedad de la revelación trinitaria? Se trata de «pensar» el «escándalo» y «pensar» la «novedad», lo que no es posible sin modificar las categorías de pensamiento. A este punto, vale la pena recordar un texto muy agudo, de F. Schlegel, que cuestiona los postulados de una cierta crítica histórica que está cerrada a la novedad y que descarta, por principio, la veracidad de lo extraordinario ${ }^{42}$.

Cuando se pone unilateralmente el énfasis en el pensar, cerrado a la auténtica novedad, el cristianismo renuncia a su irreductible identidad y, en favor de la homogeneidad (universalidad), se asimila a la cultura dominante y se reduce a lo ya conocido. Cuando, por el contrario, se pone unilateralmente el énfasis en el escándalo y en la novedad se configura un cristianismo fideísta, que exige -sin razones- una adhesión ciega y que, en la práctica, se cierra a la universalidad. El problema consiste en que, por fidelidad a la regla de fe, no se puede renunciar, por paradójico que parezca, a pensar el escándalo, dado que la universalidad forma parte del contenido de la revelación histórica.

La fe cristiana, para mantenerse fiel a su identidad, no puede renunciar ni a la historia ni a la pretensión de universalidad, y por lo tanto a la filosofía. Por una parte, no puede dejarse juzgar por la filosofía, para que sea ella la que decida qué es digno de Dios, y por otra no puede afirmar la historia, de modo fideísta, hasta desmentir la universalidad. En parte se trata del dilema que se plantea a partir de la sentencia de G. E. Lessing: «Las verdades históricas contingentes nunca pueden ser demostración de verdades necesarias» ${ }^{43}$. Si así fuera, el cristianismo debería renunciar a ser verdaderamente histórico (contingente), o debería renunciar a ser realmen-

42 «Los dos principios fundamentales de la así llamada crítica histórica son el postulado de la vulgaridad y el axioma de lo rutinario. Postulado de la vulgaridad: todo lo auténticamente grande, bueno y bello es improbable, pues es extraordinario y, por lo menos, sospechoso. Axioma de lo rutinario: tal y como son las cosas entre nosotros y alrededor de nosotros deben haber sido en todas partes, pues así todo es verdaderamente tan natural» F. Schlegel, Fragmentos del Lyceum, 25.

43 G.E. Lessing, Über den Beweis des Geistes und der Kraft, en Werke VI (Frankfurt 1965) 285, citado por H. WaLdenfels, Teología fundamental contextual (Salamanca 1994) 218. 
te universal (necesario); es decir, debería renunciar a la $\sigma \alpha ́ \rho \xi$ o al $\Lambda o ́ \gamma o \varsigma$,

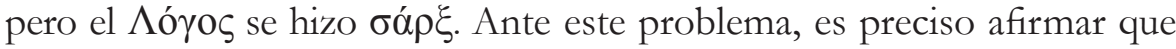
la teología no solo intenta comprender la revelación con las categorías racionales ya establecidas, sino que debe buscar ampliar la razón humana en modo que sea capaz de pensar la novedad de la revelación de Dios en la historia de Jesús.

Esta tarea exige repensar los conceptos fundamentales a la luz del Universale concretum. Es decir, a la luz de la fe en la encarnación histórica de Dios en Jesús. Cada vez que la encarnación aparece como indigna de Dios o imposible para el hombre, es necesario redefinir el concepto de Dios y el concepto de hombre; cada vez que Dios aparece como adversario del hombre, lo que hace imposible la encarnación, es necesario repensar el concepto de Dios y el concepto de hombre. Y ante la revelación trinitaria, se debe emprender la siempre inconclusa tarea de comprender la novedad trinitaria en términos universales. Tal como afirma K. Hemmerle: «Necesitamos una ontología a causa de la teología $»^{44}$. Nuevamente se constata que la auténtica sistemática trinitaria está siempre inacabada y al servicio de la expresión, en términos universales, de la experiencia histórica de la revelación de Dios en Jesús de Nazaret. Incluso K. Rahner, protagonista del giro antropológico, afirma no solo que a Dios se le conoce desde el hombre (giro antropológico), sino también que a partir de la cristología es posible saber qué es el hombre y, más ampliamente, a partir de la unión hipostática se debe elaborar una teoría más general de la relación entre Dios y el mundo ${ }^{45}$. Y así se debe proceder en los demás puntos difíciles de la cristología: no hay que preguntarse si Jesús era libre, a partir de una antropología y una definición de libertad ya establecidas, sino que, a partir del hecho de la libertad de Jesús, hay que reflexionar acerca de qué es la libertad humana, es decir, la de todo hombre.

44 K. Hemmerle, Tras las huellas de Dios. Ontología trinitaria y unidad relacional (Salamanca 2005) 25. Además: «Las respuestas de Nicea y Calcedonia no solo son aplicación, sino también transformación de la filosofía griega», 28.

45 «El paralelismo entre el conocimiento filosófico de Dios y del mundo muestra, sin embargo, que la cristología puede servir a su vez, de manera refleja, para afirmaciones ontológicas y antropológicas. Dios es conocido a partir del mundo y, a pesar de ello, también a partir de Dios puede decirse lo que es el mundo», K. RAHNER, «Problemas actuales de cristología» en Escritos de Teología, vol. I (Madrid 1961) 187; además, cf. 203-204; K. RAHNER, «Para la teología de la encarnación», 149. 
Se trata, entonces, de la fecunda invitación del papa Benedicto, expresada en su clase magistral en Ratisbona, «a ampliar el concepto y el uso de la razón» ${ }^{46}$, para hacer accesibles nuevos ámbitos de la realidad. El teólogo, guiado por la convicción de la inteligibilidad y unidad de la realidad, e iluminado por la revelación histórica de Dios en Jesús, está llamado a repensar la filosofía para hacerla capaz de acoger la nueva realidad que se ha manifestado, de hecho, en la historia.

A la luz de estas reflexiones, se puede afirmar que la fórmula cristológica «una persona en dos naturalezas» o la fórmula trinitaria «tres personas en una sustancia», las más criticadas por abandonar la historia de Jesús, son un intento -siempre parcial- de expresar en términos griegos -los únicos disponibles para los griegos- algunos aspectos de la revela-

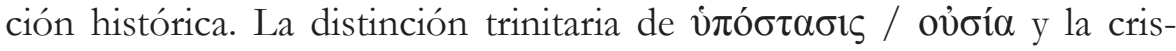

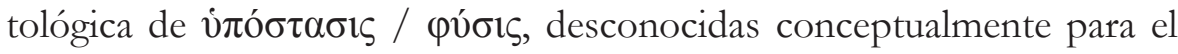
pensamiento griego, son una demostración de que estas fórmulas no son una simple aplicación deductiva del pensamiento griego al «caso Jesús de Nazaret», sino un intento de comprender conceptualmente la experiencia revelada en la historia de Jesús en su relación a nosotros y en su relación con Dios. El punto de arranque de estas fórmulas hay que buscarlo en el diálogo del pensamiento griego con la historia evangélica.

Esta tarea de pensar la revelación histórica en las categorías griegas fue realizada, como era de esperar, solo parcialmente. Así, por ejemplo, la idea griega de la inmutabilidad divina jugó un papel ambiguo en el desarrollo de la teología, porque muchas veces fue vista más como una limitación (incapacidad) que como una riqueza (fidelidad), llevando a los autores del período patrístico a comprender la historia de Jesús desde el concepto griego de inmutabilidad ${ }^{47}$. Los valentinianos, por ejemplo, vieron toda la historia del Evangelio solo como manifestación de la realidad eterna de Dios (la ley del ejemplarismo inverso), es decir, para ellos, en la economía no acontecía nada: solo era la manifestación sensible del drama eterno acontecido en el pléroma divino ${ }^{48}$. Esta parcialidad tendrá negativas consecuen-

46 Benedicto XVI, «Fe, razón y universidad. Recuerdos y reflexiones», 12 septiembre de 2006. Cf. J. Ratzinger, El Dios de la fe y el Dios de los filósofos (Madrid, 2007 [1960]) 32. También K. RAHNER afirma «que se puede ampliar el instrumental conceptual tradicional [proveniente de la filosofía griega] de la teología científica», «Problemas actuales de cristología», 188.

47 Cf. W. Pannenberg, La asimilación del concepto filosófico de Dios..., 127-133.

48 Cf. F. SAGnard, La Gnose valentinienne et le témoignage de saint Irénée (Paris 1947), 571. 
cias para la cristología pues, en ocasiones, la historia de Jesús será reducida hasta «hacerla entrar» en el sistema helenístico.

La encarnación prueba que Dios puede entrar -y que de hecho entrórealmente en la historia, en Jesús de Nazaret. Así, lo verdaderamente divino y lo auténticamente humano coinciden en un único sujeto, sin contradicción. Esta afirmación impulsa a discernir qué es lo verdaderamente divino y qué es lo auténticamente humano. Así, la encarnación exige redefinir qué es digno de Dios y qué es posible para el hombre y, en definitiva, qué es el hombre. Por ello, la buena teología ilumina la vida humana en cuanto tal: la buena teología hace más comprensible mi vida humana.

En Jesús, Dios realmente entra en contacto con la historia. De hecho, según Rahner, la afirmación: «Esa naturaleza humana está unida hipostáticamente con el Logos» es la versión metafísica del enunciado: «Esta historia humana de Jesús es la revelación absoluta y pura de Dios mismo» ${ }^{49}$. La encarnación, entonces, enseña algo de Dios, como capaz de entrar en nuestra historia, y algo de la historia humana, como capaz de acoger a Dios mismo. Una teología que vea a Dios relegado de la historia en su inmovilidad o una historia incapaz de acoger en sí misma al Absoluto, es infiel a la revelación bíblica. De este modo, la encarnación también muestra una cierta cualidad de la historia: su capacidad de Dios (bistoria capax Del), y este contacto es exigido por la soteriología. Las soluciones cristológicas y trinitarias insuficientes no son capaces de afirmar esta escandalosa y novedosa verdad: resuelven el escándalo suprimiéndolo. Pero la salvación depende de que Dios entre, verdaderamente, en contacto con el hombre. Solo si Dios asume al hombre $\mathrm{y}$ todo lo humano, el hombre puede acceder a la vida divina.

La unión hipostática indica que el hombre Jesús está realmente en comunión con Dios: Jesús humanamente está en una comunión real con Dios. Esto implica que nuestra naturaleza humana tiene la capacidad de entrar en real comunión con Dios y, por lo tanto, Dios no es inaccesible al hombre, a todo hombre; porque Jesús no es un hombre con algunas excepciones, sino perfectamente hombre (expresión más precisa que hombre perfecto). La verdadera divinidad no menoscaba la humanidad. La restricción de Heb 4, 15: «semejante a nosotros en todo, menos en el pecado» es solo aparente, pues el pecado no forma parte de la definición de hombre, sino que es un factor de deshumanización.

49 Cf. K. RAhner, Problemas actuales de cristología, 184. 
Pero, ¿cómo se verifica esta unión? En la cristología de León se encuentra claramente la profesión de fe de la necesidad de la encarnación, pero no ensaya una explicación teológica. La historia de la teología conoce autores que han ensayado un intento de explicación ${ }^{50}$, pero en León es más fuerte la profesión de fe que la explicación teológica. Ahora bien, ¿es absolutamente escandalosa la encarnación y totalmente novedosa la revelación trinitaria? ¿Hay total heterogeneidad entre Dios y los hombres? Si la encarnación y la Trinidad en términos estrictos carecen de analogías, entonces lo auténticamente cristiano sería inaccesible al hombre, la fe sería impensable y, por lo tanto, no podría haber teología. Hay algo en el hombre que hace posible la encarnación y algo en el hombre que le permite participar, al menos parcialmente, de la Trinidad ${ }^{51}$.

La transformación de las categorías muestra el profundo impacto de la historia de Jesús de Nazaret en la elaboración de la teología sistemática cristiana. San León insiste en que la historia de Jesús es el punto de arranque de la cristología, y exhorta a su auditorio a no rechazar como falso lo que parece indigno de Dios o imposible para el hombre: la historia de Jesús debe modelar el sistema, hasta mostrar que lo que parecía indigno, en realidad, no lo es, porque la encarnación lo ha demostrado de hecho (demostración a posteriori). Se verifica una primacía del acontecimiento de la revelación: a la luz de quod gestum est, hay que redefinir qué es digno de Dios. En las acciones de Jesús se revela su identidad, y la tarea constante de la cristología es tender a expresar, en términos universales, la identidad y la misión de Jesús.

De este modo, en la cristología de Calcedonia, es posible percibir el impacto de la historia personal de Jesús de Nazaret. Esta cristología no es una simple deducción dogmática que responde a la pregunta: ¿cómo debe ser un Dios encarnado?, sino que, a partir de la historia concreta de Jesús, se

$50 \quad$ Hilario de Poitiers, por ejemplo, propone una atrayente solución: la acción histórica del Espíritu Santo en la vida de Jesús obra la divinización del hombre Jesús y, así, aporta una clave para comprender el protagonismo del Espíritu en la unión entre Dios y el hombre. La historia de Jesús, conquistado por el Espíritu Santo, se vuelve una clave referida a toda la humanidad. De este modo, la redención no es comprendida como una obra exclusiva de Dios, sino también como un acto de la libertad auténticamente humana. Cf. Trin., III, 16; VIII, 25; IX, 39; IX, 54; XI, 18; In Psal., II, 27. Cf. L. LAdARIA, El Espíritu Santo en San Hilario de Poitiers (Madrid 1977) 111-139; L. LADARIA, «Cristología del Logos y cristología del Espíritu», Gregorianum 61 (1980) 353-360.

51 Según OrígenEs, «la inteligencia posee un cierto parentesco con Dios, del cual es imagen intelectual, y por esto ella puede conocer algo de la naturaleza divina», $D e$ principiis, I, 1, 7 (GCS V, p. 24). 
reconoce ( $\gamma \nu \omega \rho i \zeta \omega /$ agnosco) la integridad de su humanidad, la integridad de su divinidad y la unidad del sujeto. Todo esto, en un marco de preocupación soteriológica.

Naturalmente, tal como se anunció en la introducción, este recorrido ha estado orientado a mostrar sobre todo el impacto de la historia de Jesús en la sistemática, y en ese sentido ha sido desequilibrado al insistir en aquello que, a mi juicio, frecuentemente queda en sombra. Pero, ciertamente, esta relación es «de ida y vuelta». La teología cristiana avanza en este diálogo circular que va y viene de lo histórico a lo sistemático, en que la revelación histórica es comprendida en las categorías de pensamiento que, a su vez, ella misma modifica; y, así, la teología adquiere moldes cada vez menos inadecuados para pensar el contenido de la bistoria de Jesús, que siempre excede cualquier sistema.

Resumen: El presente artículo, desde una perspectiva histórica, busca estudiar algunos puntos particulares del desarrollo de la cristología patrística hasta Calcedonia, con el fin de mostrar cómo la revelación histórica de Dios en Jesús de Nazaret produjo un impacto que llevó a modificar el sistema de pensamiento. Si bien la cristología se fue estableciendo gradualmente en el diálogo «de ida y vuelta» entre el acontecimiento histórico y las categorías de pensamiento, el propósito de este artículo es mostrar sobre todo que la revelación histórica impactó de tal modo en la sistemática teológica que le exigió redefinir las categorías de pensamiento.

Palabras clave: Cristología, Trinidad, León Magno, Concilio de Calcedonia

Abstract: This article aims to study some particular points of the development of patristic Christology up to Chalcedon, from a historical perspective, in order to show how the historical revelation of God in Jesus of Nazareth had an impact that brought about change in the system of thought. While Christology was gradually being established in the «back and forth» dialogue between the historical event and the thought categories, the purpose of this article is to show, above all, that the historical revelation had such an impact on the theological system that redefining its thought categories was required.

Keywords: Christology, Trinity, Leo the Great, Council of Chalcedon 